\title{
Chapter 15 \\ Forest Influences on Climate and Water Resources at the Landscape to Regional Scale
}

\author{
Ge Sun and Yongqiang Liu
}

\begin{abstract}
Although it is well known that climate controls the distribution, productivity and functioning of vegetation on earth, our knowledge about the role of forests in regulating regional climate and water resources is lacking. The studies on climate-forests feedbacks have received increasing attention from the climate change and ecohydrology research communities. The goal of this study is to provide an in-depth examination of forest-climate-water interactions by synthesizing recent scientific literature on the influences of forests on climate and water resources from watershed to regional scale. The synthesis paper provides a review of the state of art of our understanding of the mechanisms of interactions of forests and climate and water resources at the landscape and regional scale. The paper presents two case studies that examine the influences of forests on microclimate, watershed hydrology, and regional climate and water resources at a small watershed to region scale using literature from the Coweeta Hydrological Laboratory in the southeast U.S. and a simulation study on the North China Shelter Belt Project. Future research gaps were identified in terms of integrated Earth System modeling to guide forest management for global change mitigation and adaptation.
\end{abstract}

Keywords Climate change - Forest hydrology • Micrometeorology • Water resources

\footnotetext{
G. Sun $(\bowtie)$

Research Hydrologist, Eastern Forest Environmental Threat Assessment Center,

Southern Research Station, USDA Forest Service, Raleigh, NC, USA

e-mail: GeSun@fs.fed.us

Y. Liu

Research Meteorologist, Center for Forest Disturbance Science, Southern Research Station, USDA Forest Service, Athens, GA, USA

e-mail: yliu@fed.fs.us
} 


\subsection{Introduction}

Being different from weather, climate refers to mean atmospheric conditions (i.e., temperature, humidity, wind, precipitation, etc.) over multiple years. The land surface, as represented by vegetation, soil, inland water bodies, is the atmospheric lower boundary where heat, water, momentum, and trace gas exchanges occur. Together with ocean and ice/snow, the atmosphere, and land surface complete the entire climate system. It is well known that climate controls the distribution (Chang 2002, p. 115), productivity and functioning of vegetation on earth (Chapin III et al. 2012) but our knowledge about the role of vegetation, forests in particular, in regulating climate is lacking (Field et al. 2007; Waring and Waring 2007, see p. 302). Forests influence climate through exchanges of energy, water, carbon dioxide, and other chemical species with the atmosphere (Bonan 2008; Cook et al. 2012), thus the studies on climate-forests feedbacks have received increasing attention from the climate change and ecohydrology research communities (Jackson et al. 2001, 2009; Vose et al. 2011; Lee et al. 2011).

Forests cover about $4.17 \times 10^{9}$ ha or $31.8 \%$ of the Earth's land surface (Chang 2002). Natural forests in a large area are generally found in regions where annual precipitation exceeds $400 \mathrm{~mm}$ and net radiation exceeds $20 \mathrm{kcal}$ (or $27 \mathrm{~W} / \mathrm{m}^{2}$ ) below which grasslands or shrublands may dominate the landscape (Sun et al. 2011a). In forested areas, precipitation often exceeds evapotranspiration rate, and thus forests are sources of surface water resources and sinks of nutrients and carbon. For example, it is estimated that over $60 \%$ of water supply comes from forest lands in the United States (Brown et al. 2008). Forest soils are regarded as 'sponge', and soil erosion is rare in forests, and thus forests provide the best water quality among all land uses. Forests can affect micro-climate by altering solar radiation and precipitation redistribution through large forest canopies (Lee 1981). However, our understanding of the influences of forests on climate is limited although much progress in this research topic has been made in the past few decades with advances in climate modeling (e.g., Charney et al. 1977; Shukla and Mintz 1982; Sud et al. 1988; Lean and Warrilow 1989; Shukla et al. 1990; Nobre et al. 1991; Dickinson and Kennedy 1992). These modeling studies show that deforestation could influence air temperature (increase or decrease) through altering land surface albedo and energy partitioning in which plants play an active role. Detailed summary on the impacts of land use change on climate are found by Pielke and Avissar (1990) and Pielke et al. (2007, 2011).

In history, humans have long recognized the roles of trees in providing shading, shelters, fibres, and ideal micro-climate, and other amenities. Forest environment is frequently viewed as 'pleasant, peaceful, sublime, and salutary' (Lee 1981). The earliest most influential publications that specifically address forest-climate relationships can be traced back to Forests and Moisture: or Effect of Forests on Humidity of Climate by John Brown published in 1877, The Earth as Modified by Human Action by G. Marsh, 1864 publish in 1874, Forests and Water in the Light of Scientific Investigation (Zon 1927), and Forest Influences (Kittredge 1948). These 
early publications were mostly propelled by disaster preventions from forest clearing by the American colonists in the nineteenth century. The U.S. Forest Service, formerly Forestry Division of the US Department of Agriculture, started to examine forest influences in the late 1800s amid public concerns of large scale deforestation that was believed to link to large floods, landslides and soil erosion Fernow, 1893. In a transmittal letter dated Nov 1, 1892 from the Division Chief B.E. Fernow to USDA Secretary regarding the state of art findings on forest-climatewater relations, Fernow wrote: '... a review of meteorological observations which have been made mostly in foreign countries, for the purpose of determining whether and to what extent forests influence climate, together with a discussion of manner in which forests affect water conditions of the earth and other matter illustrating the question of forest influences in general'. Subsequently, beginning from the 1930s, the USFS began to establish permanent forest experimental stations across the nation with initial goals to quantify influences of forest deforestation on watershed hydrology using a 'paired watershed' approach. Many of these stations have become the core Long Term Ecological Research (LTER) sites, such Coweeta, H.J. Andrew, and Hubbard Brooks, designated for long term process-based ecosystem research (Adams et al. 2008). In recognizing the close coupling among carbon, water, and energy cycles, since the early 1990s, a series of networks (i.e., FLUXNET) have been established globally to quantify flux exchanges between land surfaces and the atmosphere (Baldocchi et al. 2001). The accumulated data in the past two decades have greatly advanced our understanding global carbon and water balances under a changing climate (Law et al. 2002; Jung et al. 2010; Sun et al. 2011a, b). These longterm worldwide studies provided much of our understanding the relationships between forest covers, micrometeorology, and headwater watershed hydrology.

Historically, there is full of misconception and debate on the true influences of forests on local and regional climate and water resources around the world (Chang 2002; Andreasian 2004; Sun et al. 2006). Traditional wisdoms suggest that forests bring rains, and thus forests provide abundant water and removing forests result in droughts, loss of springs, and desertification. This perception even resulted in law suits toward the forest industry in the North Pacific of the United States where how to manage old growth Douglass fir forests has been controversial in terms of the hydrologic and ecological consequences of deforestation and forest management. To some extent, the debates are still going among scientists due to our limited understanding of the complex interactions of physical and biological process within the atmosphere-land interface and the earth systems as a whole. A good example is by Ellison et al. (2012) who argue that forest influence on climate and water resources must be evaluated at large context and the 'negative' effects of water use by trees on water yield are local and should not be exaggerated to minimize the overall 'positive' influences of forests on regional distribution of precipitation and air temperature.

During the past few decades, forests have been confirmed about their large capacity of carbon sequestration (Ryan et al. 2010; Pan et al. 2011), thus their role in slowing down the current trend of global warming (Bonan 2008). Now, we 
begin to know that forests influence redistribution of global solar energy and energy budget on earth, thus play a key role in the global hydrologic cycle (Jung et al. 2010). It has become possible to trace the movements of water vapor and atmospheric gases to develop a clearer idea of the role played by forests in moderating or regulating rainfall in different part of the world. For example, in temperate regions and tropical regions such as Southeast Asia, the main source of water vapor in the atmosphere is from evaporation at the surface of the oceans. In the Amazon Basin, however, nearly $50 \%$ of water vapor in the atmosphere in the region of Manaus and Belém appears to be 'recycled' from the forest. Oyebande (1988), Eltahir and Bras (1993), and Dickinson et al. (1993) provide good summaries of the effects of forests on rainfall and water yield in the tropics. GarciaCarreras and Parker (2011) recently reports deforestation may intensify rainfall in cut area and decrease rainfall of the surrounding areas and threats remaining rain forests in western Africa.

In general, majority of our knowledge on forest-climate-water relations is derived from small watershed studies, thus the influences of forests on local and global climate and water supply are still open for debate (Bonan 2008; Ellison et al. 2012; van der Ent et al. 2012). Our current knowledge about forests' role in moderating climate and water resources at a large watershed (Wei et al. 2008; Lin and Wei 2008; Wei and Zhang 2010) or regional scale is limited, and a broad understanding of forest-water-climate interactions is needed for determining forest management strategies in climate change mitigation and adaptation.

The overall goal of this study is to provide an in depth understanding of forestclimate-water interactions at regional to global scale by synthesizing recent scientific literature on the influences of forests on climate and water resources. Specific objectives are to: (1) present state of art of our understanding of the mechanisms of interactions of forests and climate and water resources at the landscape and regional scale, (2) present two case studies that examine the influence of forests on climate and water resources, and (3) identify research gaps that help guide future studies that can help forest management for global change mitigation and adaptation.

\subsection{Principles of Forest Influences on Climate and Water Resources}

Forests influence climate and water resources through their physical and biological functions that affect the energy, water, and biogeochemical balances (Zhao and Pitman, 2010). Key mechanisms and processes within a forest landscape are illustrated to demonstrate the close interactions between atmosphere and land surfaces and the tight forest-climate-water relationship (Fig. 15.1). 


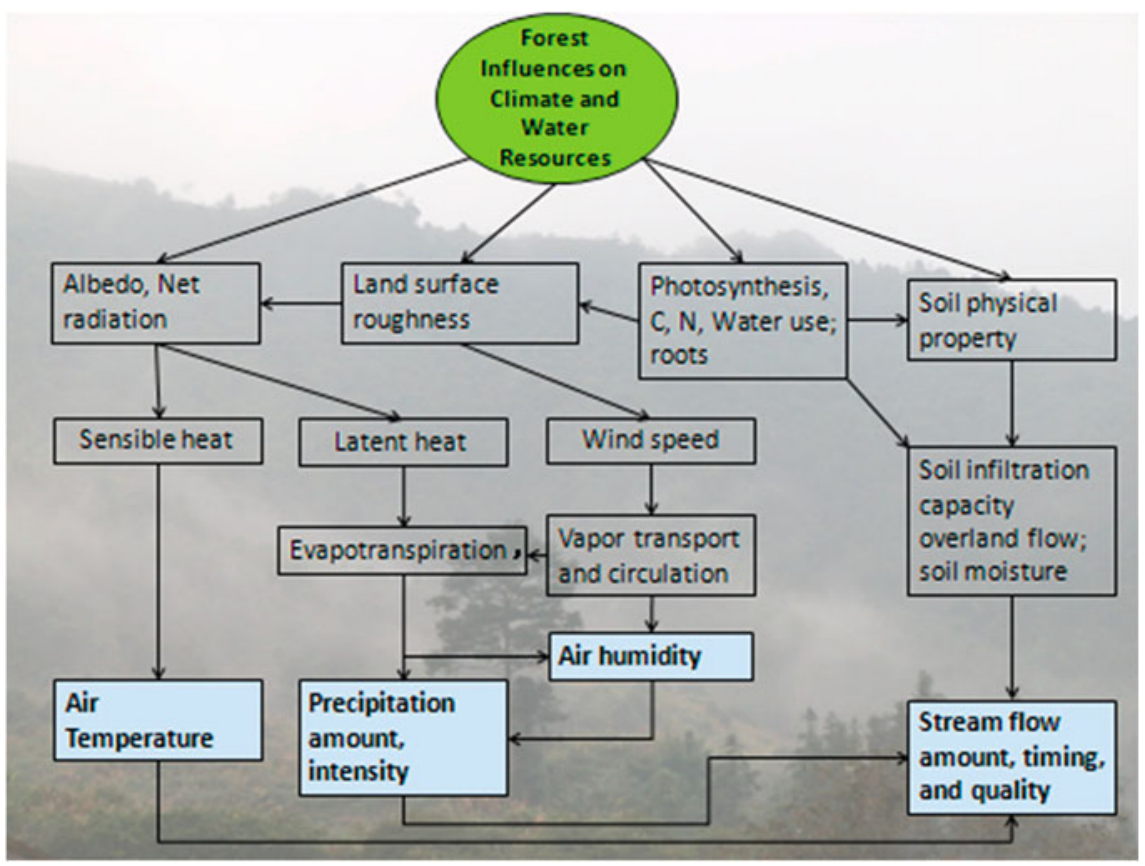

Fig. 15.1 A conceptual model describing the interactions of forests, climate, and streamflow at multiple scales (modified from Liu et al. 2008, 2010)

\subsubsection{Unique Physical Characteristics}

Forests are distinctly different from other land surfaces in physical properties both above ground and below ground in terms of the ability of light absorption and reflectance (Albedo), leaf and root biomass, surface roughness, and soil characteristics. These properties have profound influences on the energy and water balances from the ecosystem to global scale.

\subsubsection{Albedo}

Surface Albedo or light reflectance, is an important parameter that affects energy balance of ecosystems, and can be as important as greenhouse gases in affecting climate change (Betts 2000). Because forests have higher leaf area and biomass than grass or other short crops, forests generally have lower surface albedo. A lower albedo value means more solar energy available (higher net radiation) for sensible heat and latent heat, i.e., evapotranspiration. A comparison of albedo and net radiation measured for a mid-rotation (15-year-old) and young loblolly pine 


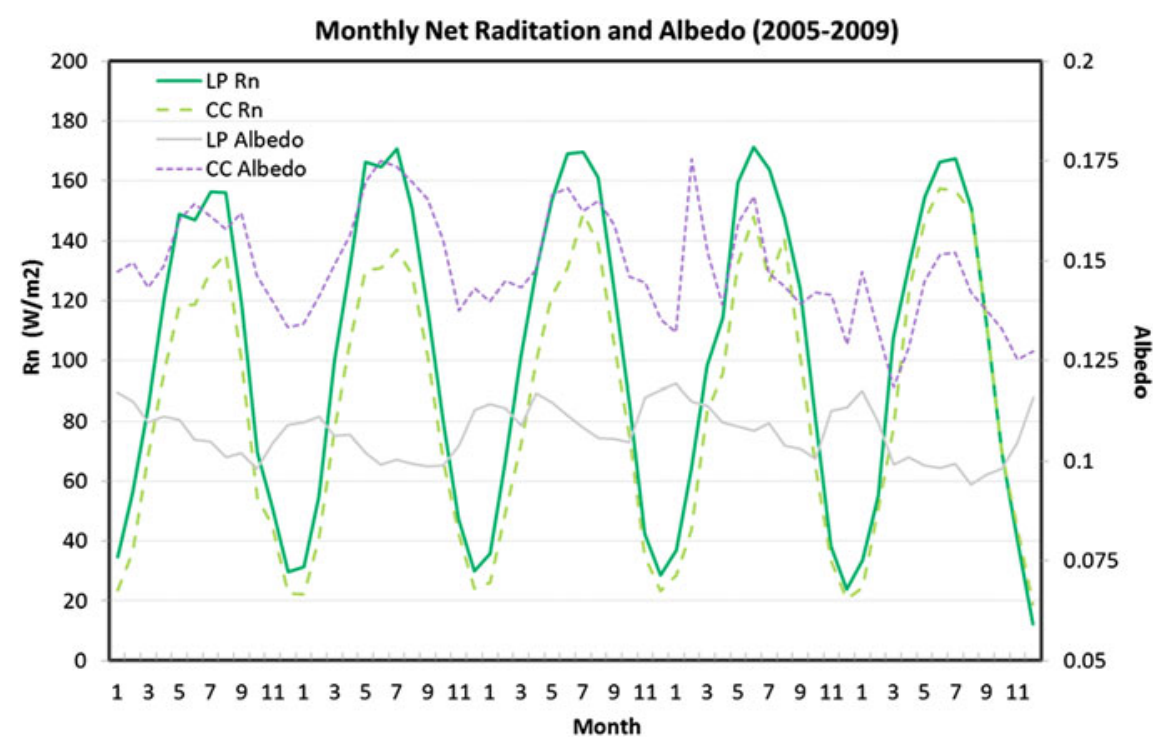

Fig. 15.2 A comparison of monthly mean net radiation $(R n)$ and albedo for a mid-rotation loblolly pine plantation $(L P)$ and a clear-cut (young plantation) $(C C)$ sites on the lower coastal plain in North Carolina, USA (see more data in Sun et al. 2010)

forest shows that albedo and net ration fluctuate seasonal and change over time due to the climate variation and plant development resulting a decrease in albedo and an increase in net radiation (Fig. 15.2) (Sun et al. 2010).

\subsubsection{Surface Roughness}

Due to uneven canopies, lands covered by tress or other vegetation have larger surface roughness than bare ground, leading to stronger turbulence and therefore smaller aerodynamic resistance for air and water vapor mixing. The measured roughness by Liu et al. (2007), for example, was 0.0058 and $0.0259 \mathrm{~m}$ for bare and maize soil, respectively, with the corresponding aerodynamic resistance ranges of 30-130 and 10-90 $\mathrm{s} \mathrm{m}^{-1}$ during the day time. Lower aerodynamic resistance for vegetated soil suggests that water loss from lands would be higher if other meteorological conditions are the same. Higher surface roughness also means lower wind speed. Recent observed global trend of decreasing wind speed is believed to do with increase in surface roughness due to increase in plant biomass and reforestation in some cases (Liu et al. 2008; Vautard et al. 2010; McVicar et al. 2012). 


\subsubsection{Leaf Area Index and Rooting Depth}

Forests have larger leaf area, deeper roots, and biomass and therefore forests can generally intercept more precipitation and transfer more water from soils to the atmosphere through evaporation and transpiration when compared to bare land or vegetated surfaces with short crops. Indeed, Leaf Area Index (LAI) (total leaf area per unit of ground surface area) is a very important land surface characteristic that controls seasonal evapotranspiration dynamics (Fig. 15.3) (Sun et al. 2011a). Indeed, leaf area index dynamics reflect not only the amount and heath of biota but also the environmental conditions such as light, water, nutrient associated with the biota. Larger LAI means higher canopy conductance and higher capacity to transfer more water from the soils to the atmosphere.

Similarly, forests generally have deep and massive rooting systems, 'the underground forests', that are advantageous over vegetated covers to extract water from soil moisture reservoirs even groundwater to meet water demand. Deep roots allow trees to adjust to droughts and stabilize water use under water stress conditions. The active functions are import machinists of climate change adaptation and ecological feedbacks to climate change (Jones et al. 2012).

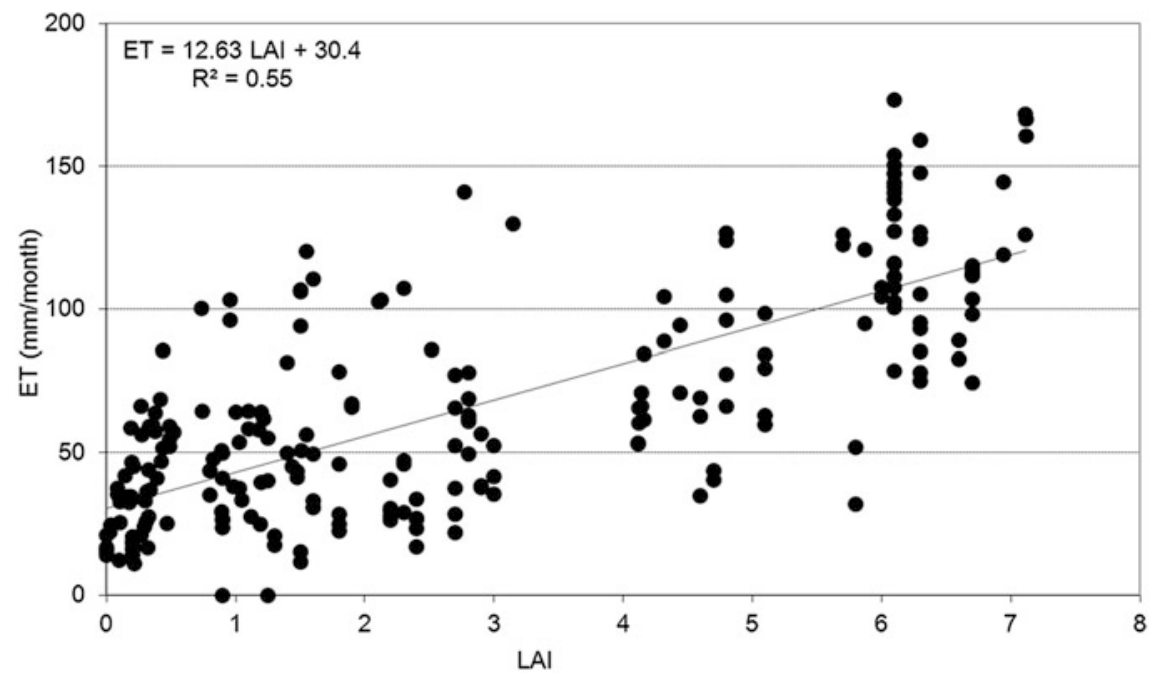

Fig. 15.3 Leaf area index $(L A I)$ is a major control for seasonal evapotranspiration (ET). Data are derived from 13 eddy flux and sapflow measurement sites across a large climatic and ecosystem gradient in China, US, and Australia (Sun et al. 2011a) 


\subsubsection{Soil Physical Properties}

Compared to soils of croplands or of other land uses, forest soils have much higher infiltration capacity Bruijnzeel, 2004. Forest soils are known for their high organic matter content derived from plant litter fall above ground and dead roots below ground that are conducive to high activities of soil organisms, high soil porosity, and higher hydraulic conductivity. For example, saturated hydraulic conductivity of the top soil layer in a mature loblolly pine forest on the North Carolina coastal plain can be as high as $700 \mathrm{~cm} / \mathrm{h}$ (Diggs 2004). Compaction caused by forest harvest operation increased bulk density from 0.22 to $0.27 \mathrm{~g} / \mathrm{cm}^{3}$, decreased saturated hydraulic conductivity from 397 to $82 \mathrm{~cm} / \mathrm{h}$ (Grace et al. 2006). Soil disturbances in intensive agriculture and forestry such as plowing, bedded, harvesting activities can dramatically degrade soil hydraulic properties. For example, deforestation and subsequently tillage practices in Iran resulted in almost a $20 \%$ increase in bulk density, $50 \%$ decrease in organic matter and total nitrogen, a 10-15\% decrease in soluble ions comparing to the undisturbed forest soil (Hajabbasi et al. 1997). The unique soil physical properties of forests explain the high soil water retention, high soil infiltration rates, minor overland flow rate, low streamflow, and high groundwater recharge commonly found in forests Zhou et al., 2010.

\subsubsection{Interactions Between Forests, Climate, and Streamflow}

As illustrated in Fig. 15.1 and the following energy balance equation, forests affect the redistribution of solar radiation into sensible and latent heat fluxes through passive (i.e., light reflection) and active physiological processes (photosynthesis, transpiration etc.). Latent heat is the energy source for evapotranspiration, a key component of the hydrologic cycle. The changes in sensible heat flux and evapotranspiration, which is accompanied with latent heat change, will modify air temperature and humidity. The change in air temperature, together with the changes in turbulence and wind, will modify atmospheric circulation. Precipitation will be affected due to the changes in circulation, temperature, and humidity.

$$
\mathrm{Rn}=(1-\alpha) * \mathrm{~S}+\mathrm{L} \text {, and } \mathrm{Rn}=\mathrm{LE}+\mathrm{H}+\mathrm{G}
$$

where $\mathrm{Rn}$ is net radiation, $\alpha$ is albedo, $\mathrm{S}$ is incoming shortwave radiation, $\mathrm{L}$ is net long wave radiation. $\mathrm{LE}$ and $\mathrm{H}$ are latent and sensible heat flux, respectively.

According the principle of water balance below, water yield or streamflow (Q) is largely controlled by ET, or LE, at a long term scale (e.g., a few years) when the change in soil water storage is negligible. However, at short temporal scale (e.g., 1 day, 1 month), soil water storage can be significant water source for Q and ET. In this case, both soil water storage and ET are important. 


$$
\mathrm{Q}=\mathrm{P}-\mathrm{ET} \pm \mathrm{S}
$$

In general, when compared to un-vegetated or less vegetated land surfaces, ET rates of trees or forests are higher, and thus streamflow is lower in forest dominated watersheds Whitehead and Robinson (1993). Worldwide 'paired watershed' experiments have confirmed this general conclusion: that is deforestation will decrease ET and increase streamflow, but afforestation or reforestation will increase ET and decrease streamflow (Zhang et al. 2001; Andreassian 2004; Brown et al. 2005; Jackson et al. 2005). However, these experiments do not track the lateral water vapor exchange in the atmosphere above the topographical watershed boundaries. It is also worthy of noting that there is a large variability for the general forest-water relationships. For example, clearing a fully forested upland watershed may increase flow by as high as $700 \mathrm{~mm} / \mathrm{year}$ in the rainforest region, but the same forest management activity may not have much effect on a wetland-dominated forested watershed (Sun et al. 2001). This large variability is presumably due to the variability of the type, extent and magnitude of forest disturbances (Sun et al. 2001; Sun et al. 2008), climatic regime including precipitation form (snow vs. rain) and distribution (Jones et al. 2012), watershed aspects and altitude (Ford et al. 2011), geology, soil depth (Scott et al. 2005), and forest types (conifer vs. deciduous) treated (Swank and Douglass 1974).

\subsection{Case Study 1: Effects of Forest Management on Water Yield at a Small Watershed Scale- The Coweeta Experiments}

The Coweeta Hydrological Laboratory is located near the town of Otto in western North Carolina in the southeastern U.S. (Fig. 15.4). Coweeta presents one of the oldest forest hydrology research sites in the world. This outdoor Lab is managed by the US Department of Agriculture Forest Service Southern Research Station and serves as one of the core Long Term Ecological Research (LTER) sites. Numerous 'paired watershed' studies have been conducted over the past 78 years at Coweeta for examining the hydrologic and ecological impacts of natural and human disturbances and design best watershed management practices. In the fall of 2009, Coweeta celebrated its 75th anniversary of establishment in 1934. Theoretical and applied research continues at Coweeta to this day. The typical experimental design followed at Coweeta is based upon the paired watershed concept in which a control watershed and a treatment watershed represent the experimental domain. The watershed pair is selected because the watersheds are known to have similar hydrological characteristics. The undisrupted continuous watershed research contributes much of our understanding of forest-climate-water relationship in the humid southern Appalachian Mountains and is an important source of our global knowledge in forest hydrology. The results from these 

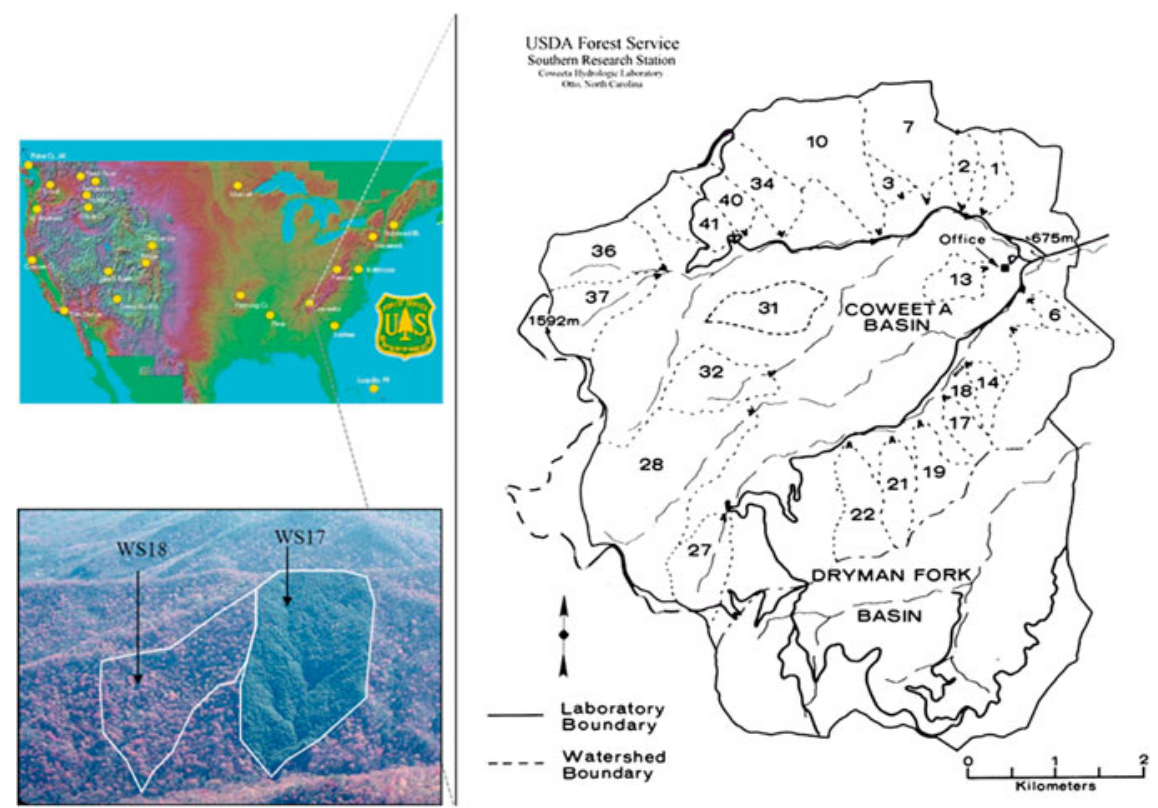

Fig. 15.4 Location of the Coweeta Hydrologic Lab that is intensively instrumented for paired watershed studies. Insert photos are to show typical watershed manipulation experiments. In this case, a tree species conversion experiment used Watershed 18 as the control (deciduous forests) and Watershed 17 as treatment (converted native deciduous to evergreen white pine forests)

experiments have been previously reported (Swank and Vose 1994; Swank et al. 1988, 2001). Below is a synopsis of key findings in terms of forest influences on water and micrometeorology at a small watersheds scale.

The climate of Coweeta is characterized as subtropical, marine climate with moderate temperatures $\left(13^{\circ} \mathrm{C}\right)$ and high abundant precipitation $(1,800 \mathrm{~mm} /$ year at low elevation but greater than 3,000 $\mathrm{mm}$ at high elevation). The parent rocks are gneiss and schistorigins and weathered residual soil mantles are deep, up to $2 \mathrm{~m}$ at foothills and $1 \mathrm{~m}$ on hillslopes. The region was heavily logged before 1923 and hardwood trees (Oak-Hickory) dominate the second growth forests.

\subsubsection{Micrometeorology}

It is well known forests affect micro-meteorology such as humidity and radiation redistribution (Swift 1972). Clearing riparian forests increases radiation reaching the forest floor thus elevate stream water temperature (Swift and Messer 1971; Swift 1973, 1982). Conifer forests (i.e., white pine plantations) have lower albedo than deciduous hardwood forests (Swift et al. 1975), thus more energy is available 
for evapotranspiration, partially explaining the $20 \%$ lower water yield observed for one watershed that was converted from native southern hardwoods to pine forests. Actual forest ET at Coweeta is generally higher than potential ET (PET) as estimated with references to water or grass surfaces (Rao et al. 2011).

\subsubsection{Seasonal and Annual Water Yield}

At Coweeta, various watershed manipulations experiments have been conducted to demonstrate and quantify the effects of forest management practices on water quantity and water quality. Although these studies were conducted in watershed less than 200 ha, they provide the basis for understanding the forest-water relations at a landscape scale and beyond, such as a regional scale (i.e., southern Appalachian Mountains).

\subsubsection{Mountain Farming}

Mountain farming experiments (Watershed 3) were conducted in 1940s to demonstrate the impacts of common farming practices in the steep southern Appalachian Mountain regions on water resources. Watershed monitoring data show that mountain farming that involved tree felling, brush burning, cattle grazing, plowing and cultivation for corns, severely reduced surface soil infiltration capacity, thus increased overland flow, peak flow rate (over 8 times higher compared to before treatment), and sediment loading rate (increase 2-80 times). Crop yield without fertilizer use was low due to intense storm and wildlife damages in the studied watershed (USFS 1948).

\subsubsection{Mountain Grazing}

About $20 \%$ of the land area in the Coweeta area was intensively grazed with fenced cattle for local economic support. Woodlands grazing experiments (Watershed 7) show that soil compactions are significant. Within the first year, soil macro-porosity of top $10 \mathrm{~cm}$ soil decreased $10 \%$ (USFS 1948). The loss of understory (palatable seedlings) lowed wind to blow litter out of the forests and reduced organic matter, thus eliminating the hydrological functions of forests (Munns 1947).

\subsubsection{Clear Cutting Forests}

To demonstrate that the significant effects of forest clear-cutting only (i.e., no trees removed from the sites) on evapotranspiration and water yield, Coweeta conducted 
a long-term repeated cutting experiment starting from 1939 (Watershed 13 on north facing slope; Watershed 17 on north facing slope). The first year following treatment in Watershed 13, water yield increased by $36 \mathrm{~cm}(60 \%)$ (Meginnis 1959) (Fig. 15.5). In 1964, the 24-year-old stand on Watershed 13 was re-cut. The first year water yield increase for the second cutting was $38 \mathrm{~cm}$, a $40 \%$ increase in water yield. On watershed 17, water yield was $41 \mathrm{~cm}(65 \%)$ higher than the effect of the south facing watershed. The differential hydrologic response to the same forest cutting activity was explained by the energy availability in the two watersheds. For the south facing watersheds, the changes in received solar energy for evapotranspiration were small before and after tree removal. In contrast, for the north facing watershed, the solar energy was only effective for evapotranspiration prior to removing the fore canopies when taller trees at the bottom of the slope transferred energy received to the soil reservoirs (Black, 1996, p. 126).

Both Watershed 13 and Watershed 17 were low elevation watersheds (outlets at 725 and $760 \mathrm{msl}$ ) where temperature was significantly higher and precipitation was significantly lower than the high elevation watersheds. Watershed 37, a steep, high elevation (watershed outlet at 1,033 msl) watershed was clear-cut in 1963

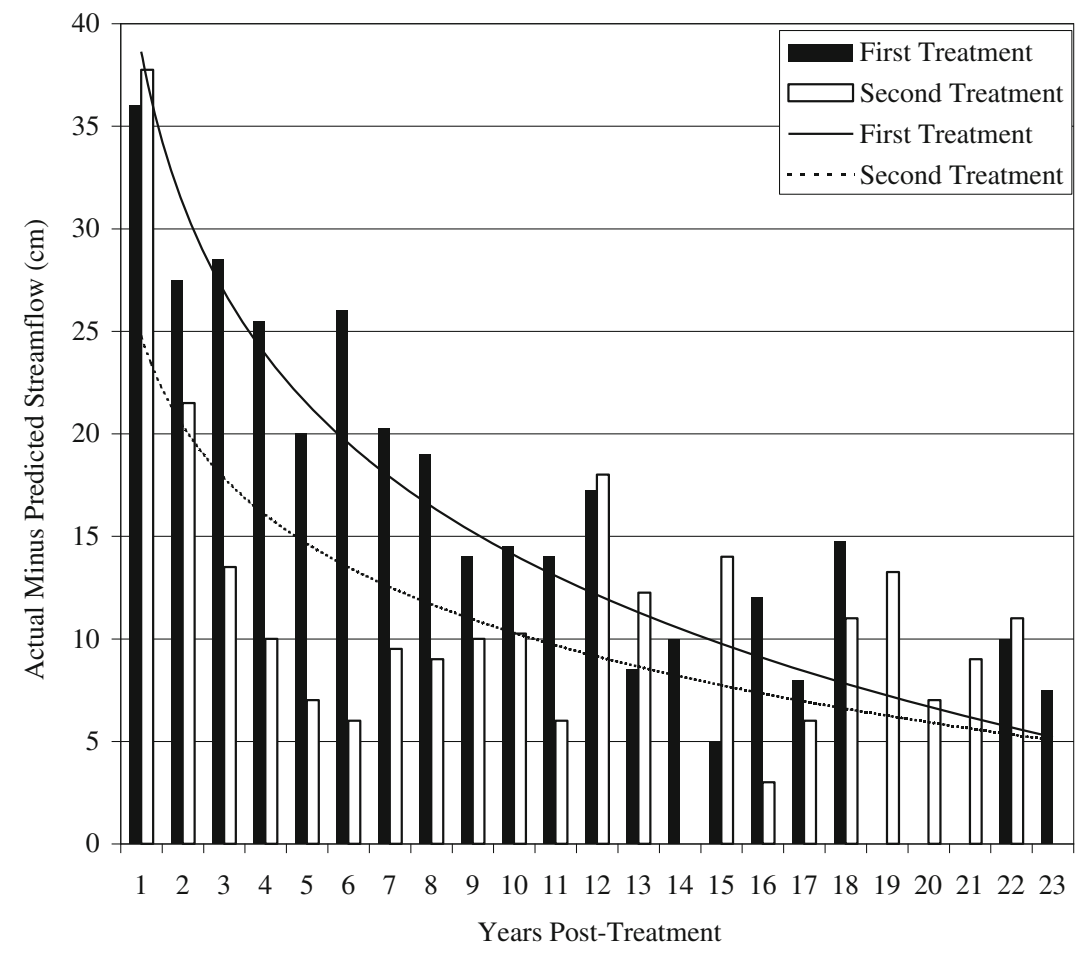

Fig. 15.5 Effects of clear-cutting on annual water yield (Watershed 13). All woody vegetation cut in 1939 and allowed to regrow until 1962 when the watershed was again clear-cut; no products removed in either treatment (Data from Coweeta Hydrologic Lab, USDA forest service) 
(Swift and Swank 1981; Swank and Helvey 1970). This produced a water yield increase of $26 \mathrm{~cm}$ the first year after the treatment. Clearly, climate regimes had influences on the hydrologic effects of forest treatments.

\subsubsection{Tree Species Conversion}

Coweeta is one the few sites that have examined the hydrologic responses to tree species change at the watershed scale (Swank and Douglass 1974; Komatsu et al. 2007). Paired watershed experiment studies (Watershed 17 and Watershed 18) concluded that converting native deciduous forests to white pine plantations has reduced flow by $20 \%$ in the 17 th year after treatment (i.e., planting white pine) in 1956 (Swank and Douglass 1974) and ET increased by $40 \%$ in the mid-2000s (Ford et al. 2007) (Fig. 15.6). The major reason was that conifers had a higher leaf areas index (up to 7.1) than the control watershed (Peak LAI for the deciduous forest less than 6.5), thus higher interception water loss and transpire water year round (Swank and Douglass 1974). Seasonally, the largest streamflow differences between the evergreen forest watershed and the deciduous forest watershed were found in the dormant winter season.

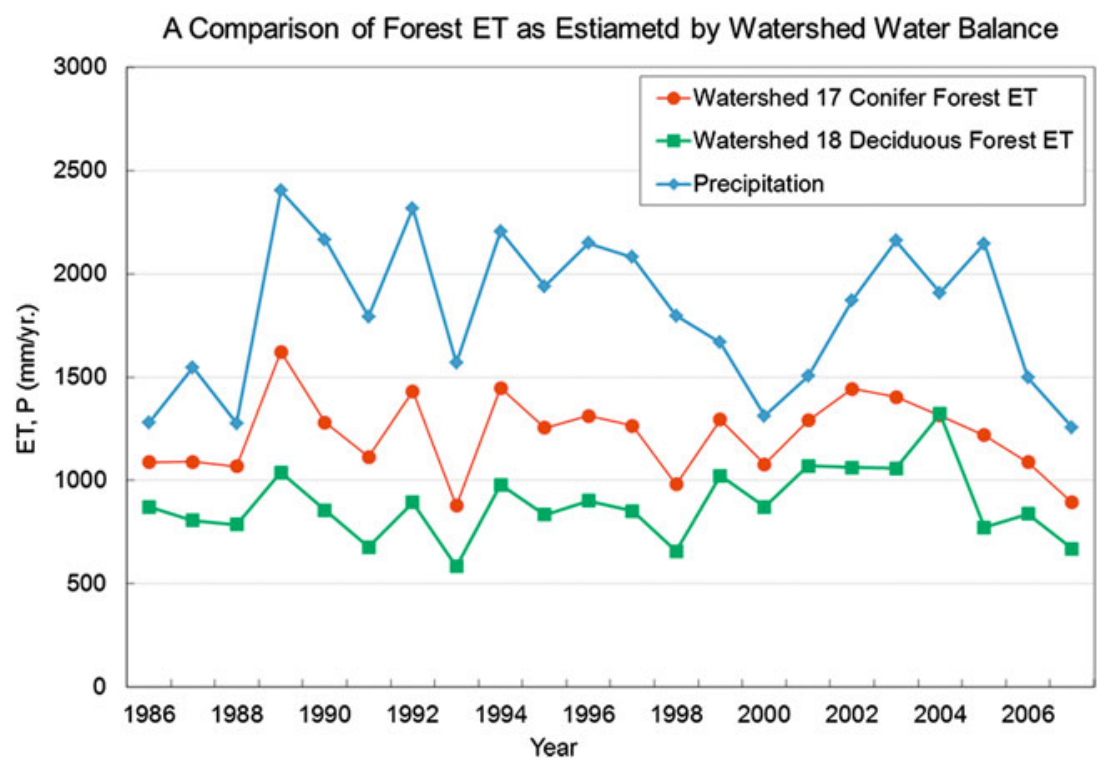

Fig. 15.6 Paired watershed experiments (Watershed 18 is a control, no management imposed) show that the watershed dominated by white pine plantations have higher evapotranspiration $(E T)$ and lower water yield $(Q)$ than the adjacent watershed dominated by native deciduous second growth forests in the Coweeta Hydrologic Laboratory in North Carolina, USA. All woody vegetation was cut in Watershed 17 in 1940 and regrowth cut annually thereafter in most years until 1955; no products removed. White pine trees planted in 1956 and released from hardwood competition as required with cutting or chemicals 


\subsection{Case Study 2: Potential Climate Influences of Large Scale Reforestation at Regional Scale-The Green Great Wall Project in Northern China}

The Green Great Wall (GGW) forest shelterbelt project in northern China was initiated in 1978 and still continues this day. The mass reforestation project aimed at curbing the southward expansion of the desert, improving climate conditions, and protecting the natural environments in the arid region. The forest shelterbelt is about 7,000 km long zonally and 400-1,700 km wide (Fig. 15.7). It stands along the southern edge of the sandy lands, closely paralleling to the Great Wall, thereby gaining the name of the Green Great Wall (GGW) (SFA 2006). The project target was to cover $60 \%$ of the project areas by $2000,85 \%$ by 2020 , and $100 \%$ by 2050. When the GGW project is completed, forest coverage in the region will increase from $5 \%$ to $15 \%$. Until now, 25.07 million hectares of forests have been planted. However, few studies have comprehensively evaluated the regional environmental and ecological influences of this large effort (Liu et al. 2008a, b).

The regional effects of GGW on climate and water were examined using a modeling approach (Liu et al. 2008a, b). Two simulations were conducted using the National Center for Atmospheric Research (NCAR) regional climate model (Version 3) (RegCM3) (Giorgi et al. 1993a, b) for the period from January 1987 to February 1988. One control simulation used present IGBP land cover data and the

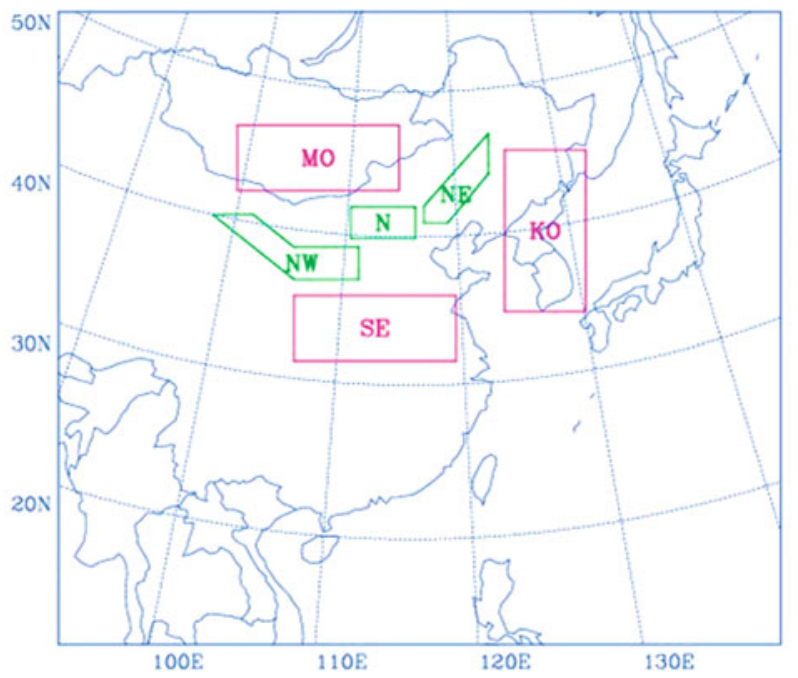

Fig. 15.7 Location of Green Great Wall project and simulation domains. The three green boxes in the middle represent the afforested areas in northwest $(N W)$, north $(N)$ and northeast $(N E)$ of China. The pink boxes are the surrounding areas in southeast (SE) China, Mongolia (MO) and Korea $(K O)$ 
other experimental simulation used hypothetical land covers assuming all croplands, grass lands, and sandy lands are replaced by evergreen needle pine foreststhe major forest type for reforestation in the region. The model operates at a 4 min time step and $50 \mathrm{~km}$ spatial resolution for 10 years.

Simulation results show that afforestation leads to overall increases in precipitation, soil moisture and air relative humidity, and decreases in wind speed and air temperature in the afforested areas. In addition, the results also show significant influences outside the afforested areas, suggesting a role of afforestation in changing the climate conditions in surrounding regions.

Simulated precipitation changes as a result of GGW were lumped into six major areas as outlined (Fig. 15.8). Precipitation increases from spring to summer, then decreases in fall, and decreases further in winter. In each season, precipitation change is generally the highest in SE, lowest in NW and MO, and in-between in N, $\mathrm{NE}$, and KO. Precipitation disturbance is positive in all afforestation areas with the

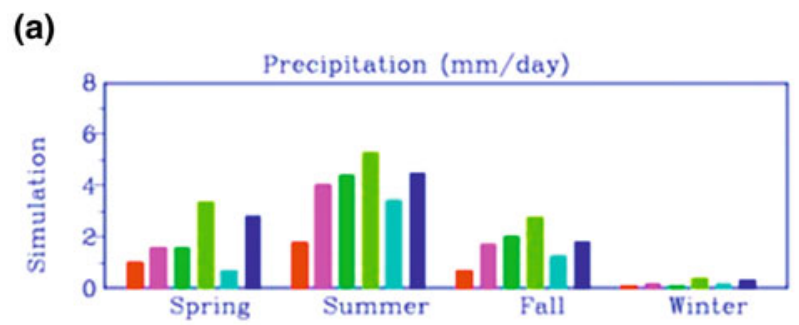

(b)

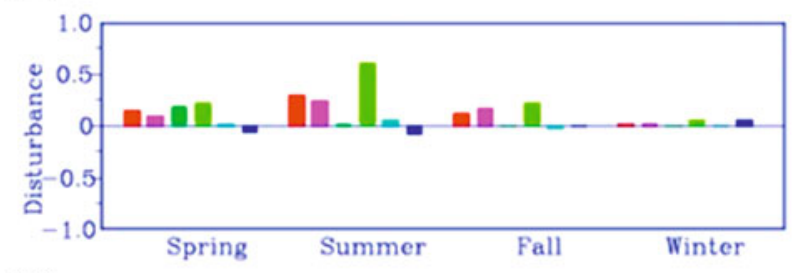

(c)

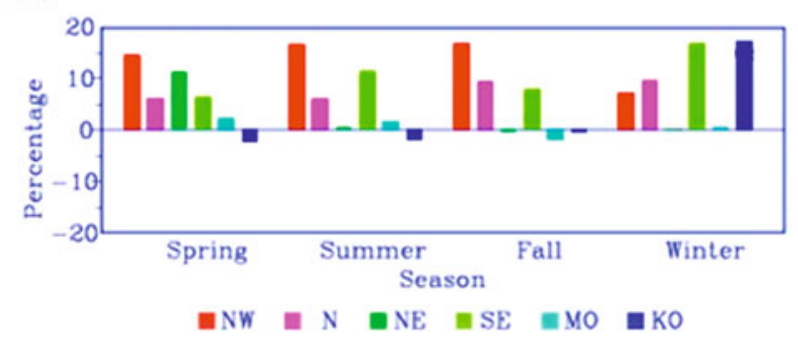

Fig. 15.8 Regional averages of precipitation (mm/day). a-c are control simulation, disturbance (the difference between experiment and control simulations), and ratio of the difference to simulation (\%). Four seasons are shown from left to right, each with the afforested areas in Northwest $(N W)$, North $(N)$, and Northeast $(N E)$ China, and the surrounding areas in Southeast China $(S E)$, Mongolia $(N O)$, and Korea $(K O)$ 
largest relative change in NW in all seasons except winter, and the lowest relative change in NE. Precipitation disturbance is also consistently positive in SE. The disturbance in $\mathrm{KO}$ is positive with a large value in winter but very small in other seasons. The disturbance is small in all seasons in MO.

The spatial patterns of precipitation changes in spring and summer are characterized by overall positive in the afforestation areas and in south of the afforestation areas over the southern North China region, which is surrounded by a negative disturbance, mainly east of the afforestation areas along the China border. The disturbance turns positive again with the most significant increase over the oceanic region south to the Korea peninsula. The spatial pattern in the fall is closer to that in the spring. In winter, a positive disturbance is dominant and occurs mostly southeast of the afforestation areas.

In comparison with the precipitation disturbance, evapotranspiration disturbance is larger in NW and N, but smaller in NE, SE and MO in spring. The same magnitude is found in NW and N, but it turns negative in NE. The disturbance is slightly positive in autumn and small in winter in the three afforested areas. Disturbance in air relative humidity is positive in all areas and all seasons except summer in NE. Air temperature is increased in winter for all areas, but varies among areas in other seasons. It is reduced by nearly $0.5^{\circ} \mathrm{C}$ in $\mathrm{NW}$, and slightly reduced in the other afforested areas with the exception of a large positive disturbance that occurs during summer in NE.

Effects of reforestation differ from precipitation and evapotranspiration in the afforested areas in that it is negative in all seasons except autumn in N. Disturbance outside of the afforestation areas can be either positive or negative, but mostly the former for the disturbance with large magnitude. These results indicate that runoff is mostly decreased in and outside the afforested areas. Disturbance in soil moisture of the surface layer varies across the regions. It is positive during all seasons for NW and SE, and positive in spring but negative during the three other seasons for $\mathrm{N}$ and $\mathrm{NE}$. The depth of the rooting layers increases after afforestation. As a result, soil moisture increases in the afforested areas.

\subsection{Knowledge Gaps and Future Research Needs}

Fossil fuel burning and land use change (e.g., deforestation) are two of the top factors that have directly contributed the ongoing climate change (IPCC 2007). Climate change is the most serious environmental problem that humans will face for a long time. Mitigating and adapting to climate change requires a comprehensive integrated approach that must consider the interactions and tradeoffs of the options. 


\subsubsection{Understanding Feedbacks Within the Forest-Climate- Human Systems}

Our knowledge about how forests will respond to climate change is limited and we know little about the consequences of management options designed to combat climate change. For example, schemes to increase carbon sequestrations in manmade forests through REDD+ (reducing greenhouse gas emissions from deforestation and forest degradation) could negatively impacts biodiversity (Parrotta 2012) and water resources (Jackson et al. 2005) and the environment (Cao 2008) if not properly implemented. We need to better understand the feedbacks between climate change and human response and actions using a system approach (Avila et al. 2012). Current climate change models are not reliable for local predictions and the Earth system models that incorporate land surface processes and atmospheric processes and human influences are still in their infancy (Bonan 2008; Angelini et al. 2011). Forests can affect regional climate processes and variability at long time scales (Notaro and Liu, 2006; 2008). Similar to oceans, the land has the capacity to retain anomalous signals over a much longer period than the atmosphere. Land surface processes could contribute to long-term atmospheric variability by passing their relatively slow anomalous signals to the atmosphere (e.g., Yeh et al. 1984; Dickinson and Handerson-Sellers 1988; Delworth and Manabe 1988; Vinnikov et al. 1996; Liu and Avissar 1999; Koster and Suarez 1995).

Forest-climate interactions contribute to local and regional climate variability at interannual and decadal scales (Zeng et al. 2000). Landscapes in Amazon, the Sahel, western Africa tropical rainfall forests, northwest China have changed dramatically since the 1970 s as a result of deforestation and over-cultivation (Sampson 2004). These changes have been linked to some regional climate disasters such as the prolonged drought in northern Africa during the 1970s (Charney 1975; Xue and Shukla 1993) and flooding and dust storms in China. The declined vegetation converge in the southern United States in the 19th century and early 20th century due to agriculture and industrial activities might be a contributor to the drying climate and severe dust bowls during the 1930s. Future global climate change suggests ted that a large portion of the temperate deciduous forests in the Southeast would be replaced with temperate deciduous savanna in response to the projected climate change (Neilson et al. 1998, 2005). Notaro et al. (2007) indicated that, for the projected future climate change due to the greenhouse effect, tree coverage is expected to increase in many regions, including southeastern U.S. Studying land-atmosphere interaction has emerged as one of the most active research areas in atmospheric and hydrological sciences in the past decades, partly due to the increasing attention to human activity related to regional environmental changes (Bonna 2008). 


\subsubsection{Improving Earth System Modeling Capacity: Bridging Landscape Processes and Regional Climate and Hydrology}

Climate is the ultimate driving force for landscape-scale hydrologic processes which are naturally linked to local climate. Traditional watershed or landscape hydrological studies largely assume climate as a stationary external force, and hydrologic processes have no influences on local climate. For example, we know that reforestation will increase ET at the watershed scale, but we rarely tract how far and where the water vapor will travel across the physical watershed boundaries. Scaling empirical observations at the landscape scale to regional scale is still a difficult task and remains to be an active research area in landscape ecology and regional and global hydrology.

Simulating the true interactions and feedbacks between land surface processes such as forest vegetation functions and climate systems requires the tight coupling of regional climate models and landscape vegetation dynamics, and global circulation climate models or regional climate models (Phipps et al. 2011). Existing integrated dynamic vegetation models (DGVMs) have the capacity to simulate natural forest vegetation dynamics and the influences of external disturbances such as climate variability (e.g., drought and flood) and physical and chemical climate effects (e.g., greenhouse gases), species invasion, wildfire, insect outbreak on ecological processes (i.e., water and carbon cycles). DGVMs simulate daily or monthly carbon, water and nitrogen cycles driven by the changes in atmospheric chemistry including ozone, nitrogen deposition, $\mathrm{CO}_{2}$ concentration, climate, land-use and land-cover types and disturbances. DGVMs usually include four core components of biophysics, plant physiology, soil biogeochemistry, and dynamic vegetation and landuse. Examples of DGVMs include HYBRIDS (Friend et al. 1997), MC1 (Bachelet et al. 2001), the Lund-Potsdam-Jena (LPJ) (Sitch et al. 2003), CLM (Levis et al. 2004), IBIS (Foley et al. 2005), and the DELM (Tian et al. 2009).

Efforts have been made to couple DGVMs into Global Circulation Models (GCMs) and Regional Climate Model (RCMs). For example, CLM is fully coupled with the National Center for Atmosphere Research's Community Earth System Model (CESM) and WRF (Jin et al. 2010), respectively. The coupled models are able to simulate the impacts on and feedbacks to climate from dynamic changes in forests. They will be especially useful for understanding the roles of afforestation in mitigating the impacts of climate change discussed above. For further assessing the mitigation roles and making management plans, comprehensive modeling systems such as the integrated Regional Earth System Model (iRESM) (http://www.pnl.gov/atmospheric/iresm/) are needed. iRESM is a modeling framework developed in the Pacific Northwest National Laboratory (PNNL) to address regional human-environmental system interactions in response to climate change and the uncertainties therein. The framework consists of a suite of integrated models representing regional climate change, regional climate policy, and the regional economy. 


\subsubsection{Understanding the Roles of Afforestation in Mitigating Negative Effects of Climate Change}

Forest ecosystems are large carbon sinks (Pan et al. 2011) and thus could play an important role in mitigating climate change. Sustainable forest management strategy that aims at maintaining or increasing forest carbon stocks will not only produce sustained yield of timber or energy but also will generate the largest sustained mitigation benefit. For example, a large afforestation effort that plans to plant about 18 million acres of new trees to replace pasture and farming lands by 2020 are being implemented in the southeastern US, as well as in Great Lake states and the Corn Belt states (Watson 2009) in the U.S. The project would be even larger than the one carried out by the Civilian Conservation Corps during the Great Depression, which planted 3 billion trees from 1933 to 1942.

Forests also can modulate climate by controlling energy and water transfers. If warmer conditions increase vegetation coverage, for example, evapotranspiration and solar radiation absorbed on the surface will increase. The change in evapotranspiration, which often plays a more important role, will lead to cooling. The feedback from evapotranspiration would partially offset any greenhouse warming. Through such feedback mechanisms, ecosystems influence their local environment and combined with their ability to sequester atmospheric $\mathrm{CO}_{2}$, can act to mitigate climate change impacts.

Small watershed studies worldwide clearly show that forests are biological water pumps', (Makarieva et al. 2009) and they consume large amount of water to realize other ecosystem services (e.g., carbon sequestration and moderating climate). This has been confirmed worldwide (Scott and Lesch 1997; Robinson et al. 2003; Ice and Stednick 2004). Thus, when other conditions are equal, compared to other land uses, such as grasslands and urban lands, forested watersheds have lower total water yield (Bosh and Hewlett 1982; Zhang et al. 2008a, b; Wang et al. 2009; 2011) and peakflow rates/floodings (Eisenbies et al. 2007; Alila et al. 2009), and thus reforestation can help mitigating the negative impacts of extreme storm events (Ford et al. 2011; Vose et al. 2011) in addition to achieving carbon sequestration benefits. Forests protect water quality (e.g., preventing soil erosion and sediment loading in streams) under a changing climate that increases rainfall intensity in some regions. However, these basic understanding of forest-water relationships are based on watershed studies and data at large basin and regional scales are still lacking. While the important role of forests in mitigating global change through modifying the carbon cycle has been widely recognized, their importance to mitigate extreme climate and hydrology (floods and droughts) through the land-atmosphere interaction has yet to be fully explored and quantified (van der Ent et al. 2010; Vose et al. 2012). This is exemplified by the recent debate on forests influences on regional water supply (Ellison et al. 2012; van der Ent et al. 2012) and forests' role in flood controls (Calder et al. 2007; Bradshaw et al. 2007; Laurence 2007; Van Dijk et al. 2009). Coupled climate-vegetation-hydrology models should be useful tools for understanding the role of the vegetation in 
regional and global climate and water cycles and design management strategies and options to adapt to a new environment.

Acknowledgments Funding for this study was supported by the USDA Forest Service Southern Research Station and also by the Chinese Academy of Science CAS/SAFEA International Partnership Program for Creative Research Teams of 'Ecosystem Processes and Services'.

\section{References}

Alila Y, Kuras PK, Schnorbus M, Hudson R. Forests and floods: a new paradigm sheds light on age-old controversies. Water Resour Res. 2009;45:W08416. doi:10.1029/2008WR007207.

Adams MB, Loughry LH, Plaugher LL. Experimental forests and ranges of the USDA forest service, revised. US For Serv Gen Tech Rep NE-GTR-321; 2008. p. 183.

Andreassian V. Waters and forests: from historical controversy to scientific debate. J Hydrol. 2004;291:1-27.

Angelini IM, Garstang M, Davis RE, Hayden B, Fitzjarrald DR, Legates DR, Greco S, Macko S, Connors V. On the coupling between vegetation and the atmosphere. Theor Appl Climatol. 2011. doi:10.1007/s00704-010-0377-5.

Avila FB, Pitman AJ, Donat MG, Alexander LV, Abramowitz G. Climate model simulated changes in temperature extremes due to land cover change. J Geophys Res. 2012;117:D04108. doi:10.1029/2011JD016382.

Bachelet D, Lenihan JM, Daly C, Neilson RP, Ojima DS, Parton WJ. MC1: a dynamic vegetation model for estimating the distribution of vegetation and associated carbon, nutrients, and water. Technical documentation, version 1.0. Gen Tech Rep PNW-GTR-508. Portland: US Department of Agriculture, Forest Service, Pacific Northwest Research Station; 2001.

Betts RA. Offset of the potential carbon sink from boreal forestation by decreases in surface albedo. Nature. 2000;408:187-90.

Black P. Watershed hydrology. 2nd ed. CRC Press: Boca Raton; 1996. p. 449.

Baldocchi D, Falge E, Gu L, Olson R, Hollinger D, Running S, Anthoni P, Bernhofer C, Davis KJ, Evans R, Fuentes J, Goldstein A, Katul G, Law BE, Lee Z, Malhi Y, Meyers T, Munger JW, Oechel W, Paw U KT, Pilegaard K, Schmid HP, Valentini R, Verma S, Vesala T, Wilson KB, Wofsy S. FLUXNET: a new tool to study the temporal and spatial variability of ecosystem-scale carbon dioxide, water vapor, and energy flux densities. Bull Am Meteorol Soc. 2001;82(11):2415-34.

Bonan GB. Forests and climate change: forcings, feedbacks, and the climate benefits of forests. Science. 2008;320:1444-9.

Bradshaw CJA, Sodhi NS, Peh KS-H, Brook BW. Global evidence that deforestation amplifies flood risk and severity in the developing world. Global Change Biol. 2007;13:2379-95. doi:10.1111/j.1365-2486.2007.01446.x.

Bosch JM, Hewlett JD. A review of catchment experiments to determine the effect of vegetation changes on water yield and evapotranspiration. J Hydrol. 1982;55:3-23.

Brown AE, Zhang L, McMahon TA. A review of paired catchment studies for determining changes in water yield resulting from alterations in vegetation. J Hydrol. 2005;310:1-34.

Brown TC, Hobbins MT, Ramirez JA. Spatial distribution of water supply in the coterminous United States. J Am Water Resour Assoc. 2008;6(44):1474-87.

Bruijnzeel LA. Hydrological functions of tropical forests: not seeing the soils for the trees. Agric Ecosyst Environ. 2004;104:185-228.

Charney JG. Dynamics of deserts and drought in the Sahel. Quart J Roy Meteor Soc. 1975;101:193-202. 
Calder IR, Smyle J, Aylward B. Debate over flood-proofing effects of planting forests. Nature. 2007;450:945. doi:10.1038/450945b.

Cao S. Why large-scale afforestation efforts in China have failed to solve the desertification problem. Environ Sci Technol. 2008;42:1826-31.

Chang M. Forest hydrology: an introduction to water and forests. BocaRaton: CRC Press; 2002. p. 373.

Chapin III FS, Matso PA, Vitousek PM, Chapin MC. Principles of terrestrial ecosystem ecology. 2nd ed. New York: Springer; 2012. p. 544.

Charney JG, Quirk WJ, Chow SH, Kornfield J. A comparative study of the effects of albedo change on drought in semi-arid regions. J Atmos Sci. 1977;34:1366-85.

Cook BI, Anchukaitis KJ, Kaplan JO, Puma MJ, Kelley M, Gueyffier D. Pre-Columbian deforestation as an amplifier of drought in Mesoamerica. Geophys Res Lett. 2012;39:L16706. doi:10.1029/2012GL052565.

Delworth T, Manabe S. The influence of potential evaporation on the variabilities of simulated soil wetness and climate. J. Climate. 1988;1:523-47.

Dickinson RE, Henderson-Sellers A. Modeling tropical deforestation: a study of GCM landsurface parameterizations. Quart J Roy Meteor Soc. 1988;114:439-62.

Dickinson RE, Kennedy P. Impacts on regional climate of Amazon deforestation. Geophy Res Lett. 1992;19(19):1947-50.

Dickinson RE, Durbudge TB, Kennedy PJ, McGuffie K, Pitman AJ 1993 Tropical deforestation: modeling local- to regional-scale climate change. J Geophy Res. 1993;98(D4):7289-315.

Diggs JA. 2004. Simulation of nitrogen and hydrology loading of forested fields in eastern North Carolina using DRAINMOD-N 11. M.S. Thesis, North Carolina State University, Raleigh, NC; 2004. p. 155.

Eisenbies MH, Aust WM, Burger JA, Adams MB. Forest operations, extreme events, and considerations for hydrologic modeling in the Appalachians-A review. For Ecol Manage. 2007;242:77-98. doi:10.1016/j.foreco.2007.01.051.

Ellison D, Futter MN, Bishop K. On the forest cover-water yield debate: from demand- to supply-side thinking. Global Change Biol. 2012;18:806-820. doi:10.1111/j.13652486.2011.02589.x.

Eltahir EAB, Bras RL. On the response of the tropical atmosphere to large-scale deforestation. Quart J Roy Meteor Soc. 1993;119:779-93.

Field CB, Lobell DB, Peters HA, Chiariello NR. Feedbacks of terrestrial ecosystems to climate change. Annu Rev Environ Resour. 2007;32:1-29.

Foley JA, DeFries R, Asner GP, Barford C, Bonan G, Carpenter SR, Chapin FS, Coe MT, Daily GC, Gibbs HK, Helkowski JH, Holloway T, Howard EA, Kucharik CJ, Monfreda C, Patz JA, Prentice IC, Ramankutty N, Snyder PK. Global consequences of land use. Science. 2005;309:570-4.

Ford CR, Hubbard RM, Kloeppel BD, Vose JM. A comparison of sap flux-based evapotranspiration estimates with catchment-scale water balance. Agric For Meteorol. 2007;145:176-85. doi:10.1016/j.agrformet.2007.04.010.

Ford CR, Laseter SH, Swank WT, Vose JM. Can forest management be used to sustain waterbased ecosystem services in the face of climate change? Ecol Appl. 2011;21:2049-67.

Fernow BE. Forests influences (1972 reprint version). No. 7 Bulletin of U.S. Forest service; 1893.

Friend A, Stevens A, Knox R, Cannell M. A process-based, terrestrial biosphere model of ecosystem dynamics (Hybrid v3.0). Ecol Model. 1997;95:249-87.

Garcia-Carreras L, Parker DJ. How does local tropical deforestation affect rainfall? Geophys Res Lett. 2011;38:L19802. doi:10.1029/2011GL049099.

Grace MJ III, Skaggs RW, Cassel DK. Soil physical changes associated with forest harvesting operations on an organic soil. Soil Sci Soc Am J. 2006;70:503-9.

Giorgi F, Marinucci MR, De Canio G, Bates GT. Development of a second generation regional climate model (RegCM2), I, boundary layer and radiative transfer processes. Mon Weather Rev. 1993a;121:2794-813. 
Giorgi F, Marinucci MR, De Canio G, Bates GT. Development of a second generation regional climate model (RegCM2), II, Convective processes and assimilation of lateral boundary conditions. Mon Weather Rev. 1993b;121:2814-32.

Hajabbasi MA, Jalalian A, Karimzadeh HR. Deforestation effects on soil physical and chemical properties, Lordegan, Iran. Plant Soil. 1997;1997(190):301-8. doi:10.1023/A:1004243702208

Ice GG, Stednick JD. A century of forest and wildland watershed lessons. Soc Am Foresters. 2004;287.

Intergovernmental Panel on Climate Change (IPCC), Climate Change 2007.

Jackson RB, Carpenter SR, Dahm CN, McKnight DM, Naiman RJ, Postel SL, Running SW. Water in a changing world. Ecol Appl. 2001;11:1027-45. doi:10.1890/10510761(2001)011[1027:WIACW]2.0.CO;2.

Jackson RB, Jobbagy EG, Avissar R, Roy SB, Barrett DJ, Cook CW, Farley KA, Le Maitre DC, McCarl BA, Murray BC. Trading water for carbon with biological carbon sequestration. Science. 2005;310:1944-7. doi:10.1126/science.1119282.

Jackson RB, Jobbágy EG, Nosetto MD. Ecohydrology in a human-dominated landscape. Ecohydrology. 2009;2:383-9. doi:10.1002/eco.81.

Jones JA, Creed IF, Hatcher KL, Warren RJ, Adams MB, Benson MH, Boose E, Brown WA, Campbell JL, Covich A, Clow DW, Dahm CN, Elder K, Ford CR, Grimm NB, Henshaw DL, Larson KL, Miles ES, Miles KM, Sebestyen SD, Spargo AT, Stone AB, Vose JM, Williams MW. Ecosystem processes and human influences regulate streamflow response to climate change at long-term ecological research sites. BioScience. 2012;62(4):390-404. doi:10.1525/ bio.2012.62.4.10.

Jin J, Miller NL, Schlegel N. Sensitivity Study of Four Land Surface Schemes in the WRF Model. Adv Meteorol. 2010 doi: 10.1155/2010/167436.

Jung M, Reichstein M, Ciais P, Seneviratne SI et al. Recent decline in the global land evapotranspiration trend due to limited moisture supply. Nature. 2010;467:951-54.

Kittredge J. Forest influences. New York: McGraw-Hill Book Co.; 1948. p. 99-114.

Komatsu H, Tanak N, Kume T. Do coniferous forests evaporate more water than broad-leaved forests in Japan? J Hydrol. 2007;336:361-75.

Koster RD, Suarez MJ. The relative contributions of land and ocean processes to precipitation variability. J Geophys Res. 1995;100(D7):13775-790.

Laurence WF. Environmental science: forests and floods. Nature. 2007;449:409-10.

Levis S, Bonan GB, Vertenstein M, Oleson KW. The Community Land Model's dynamic global vegetation model (CLM-DGVM): Technical description and user's guide. NCAR Tech. Note TN-459+IA, 2004;50 pp.

Law BE, Falge E, Gu L, Baldocchi DD, Bakwin P, Berbigier P, Davis K, Dolman AJ, Falk M, Fuentes JD, Goldstein A, Granier A, Grelle A, Hollinger D, Janssens IA, Jarvis P, Jensen NO, Katul G, Mahli Y, Matteucci G, Meyers T, Monson R, Munger W, Oechel W, Olson R, Pilegaard K, Paw UKT, Thorgeirsson H, Valentini R, Verma S, Vesala T, Wilson K, Wofsy S. Environmental controls over carbon dioxide and water vapor exchange of terrestrial vegetation. Agric For Meteorol. 2002;113:97-120. doi:10.1016/S0168-1923(02)00104-1.

Lean J, Warrilow DA. Simulation of the regional climatic impact of Amazon deforestation. Nature. 1989;342:411-13.

Lee R. Forest hydrology. New York: Columbia University Press; 1981. pp. 498-509.

Lee X, Goulden ML, Hollinger DY, Barr A, Black TA, Bohrer G, Bracho R, Drake B, Goldstein A, Gu L, Katul G, Kolb T, Law B, Margolis H, Meyers T, Monson R, Munger W, Oren R, Paw U KT, Richardson AD, Schmid HP, Staebler R, Wofsy S, Zhao L. Observed increase in local cooling effect of deforestation at higher latitudes. Nature. 2011;479:384-87.

Lin Y, Wei X. The impact of large-scale forest harvesting on hydrology in the Willow Watershed of Central British Columbia. J Hydrol. 2008;359:141-9.

Liu S, Lu L, Mao D, Jia L. Evaluating parameterizations of aerodynamic resistance to heat transfer using field measurements. Hydrol Earth Syst Sci. 2007;11:769-83. 
Liu Y-Q, Avissar R. A study of persistence in the land-atmosphere system with a fourth-order analytical model. J. Climate. 1999;12:2154-68.

Liu Y-Q, Stanturf J, Lu H. Modeling the potential of the NorthernChina forest shelterbelt in improving hydroclimate conditions. J Am Water Resour Assoc. 2008;44(5):1176-92.

Liu Y-Q. A numerical study on hydrological impacts of forestrestoration in the southern United States. Ecohydrology. 2010;4:299-314.

Liu JG, Li SX, Ouyang ZY, Tam C, Chen XD. Ecological and socioeconomic effects of China's policies for ecosystem services. Proc Natl Acad 894 Sci USA. 2008b ;105(28):9477-482.

Makarieva AM, Gorshkov VG, Li B-L. Precipitation on land versus distance from the ocean: evidence for a forest pump of atmospheric moisture. Ecol Complex. 2009;6:302-7.

Marsh GP. Man and nature; or, physical geography as modified by human action. New York: C. Scribner; 1864.

Meginnis HG. Increasing water yields by cutting forest vegetation. In: Symposium of Hannoversch-Munden. Publ. 48. Louvain, Belgium: International Association of Scientific Hydrology: 1959;59-68.

McVicar TR, Roderick ML, Donohue RJ, Li LT, Van Niel TG, Thomas A, Grieser J, Jhajharia D, Himri Y, Mahowald NM, Mescherskaya AV, Kruger AC,Rehman S, Dinpashoh Y. Global review and synthesis of trends in observed terrestrial near-surface wind speeds: implications for evaporation. J Hydrol. 2012;416-7:182-205.

Munns EN. Forest hydrology in the Appalachians. J Soil Water Conserv. 1947;2:71-6.

Neilson RP, Prentice IC, Smith B, Kittel TGF, Viner D. Simulated changes in vegetation distribution under global warming. In: Watson RT, Zinyowera MC, Moss RH, Dokken DJ, editors. The regional impacts of climate change: an assessment of vulnerability. Cambridge: Cambridge University Press; 1998. p. 439-56.

Neilson RP, Pitelka LF, Solomon A, Nathan R, Midgley GF, Fragoso J, Lischke H, Thompson K. Forecasting regional to global plant migration in response to climate change: challenges and directions. Bioscience. 2005;55:749-59.

Nobre CA, Sellers PJ, Shukla J. Amazonian deforestation and regional climate change. J Clim. 1991;4:957-88.

Notaro M, Vavrus S, Liu Z. Global vegetation and climate change due to future increases in $\mathrm{CO} 2$ as projected by a fully coupled model with dynamic vegetation. J Clim. 2007;20:70-90.

Notaro M, Liu Z. Observed vegetation-climate feedbacks in the United States. J Clim. 2006;19:763-86.

Notaro M, Liu Z. Statistical and dynamical assessment of vegetation feedbacks on climate over the boreal forests. Clim Dyn. 2008;31:691-712.

Oyebande L. Effects of tropical forests on water yield. In: Reynolds ERC, Reynolds FB, editors. Forest, climate, and hydrology: regional impacts. Japan: The United Nations University; 1988. p. 16-50.

Pan Y, Birdsey RA, Fang J, Houghton R, Kauppi PE, Kurz WA, Phillips OL, Shvidenko A, Lewis S, Canadell JG, Ciais P, Jackson RB, Pacala SW, McGuire AD, Piao S, Rautiainen A, Sitch S, Hayes D. A large and persistent carbon sink in the world's forests. Science. 2011;333:988-93.

Parrotta J. Understanding Relationships between biodiversity, Carbon, forests and people: The key to achieving REDD+Objectives. A global assessment report. IUFRO on behalf of the Collaborative Partnership on Forests (CPF), Global Forest Expert Panel on Biodiversity, Forest Management and REDD+; 2012.

Phipps SJ, Rotstayn LD, Gordon HB, Roberts JL, Hirst AC, Budd WF. The CSIRO Mk3L climate system modelversion 1.0-Part 1: description and evaluation. Geosci Model Dev Discuss. 2011;4(1):219-287. doi:10.5194/gmdd-4-219-2011.

Pielke RA, Avissar R. Influence of landscape structure on local andregional climate. Landscape Ecol. 1990;4:133-55.

Pielke RA, Adegoke J, Beltr A, An-Przekurat CA, Hiemstra J, Lin J, Nair US, Niyogi D, Nobis TE. An overview of regional land-use and land-cover impacts on rainfall. Tellus. 2007;59B:587-601. 
Pielke RA Sr, et al. Land use/land cover changes and climate: modeling analysis and observational evidence, Wiley Interdiscip. Rev Clim Change. 2011;2:828-50. doi:10.1002/ wcc.144.

Rao L, Sun G, Ford CR, Vose J. Modeling potential evapotranspiration of two forested watersheds in the Southern Appalachians, USA. Trans ASABE. 2011;54(6):2067-78.

Ryan MG, Harmon ME, Birdsey RA, Giardina CP, Heath LS, Houghton RB, Jackson RB, McKinley DC, Morrison J, Murray BC, Pataki DE, Skog KE. A synthesis of the science on forests and carbon for U.S. Forests. Issue 13 of Issues in Ecology; 2010.

Robinson M, Cognard-Plancq AL, Cosandey C et al. Studies of the impact of forests on peak flows and baseflows: a European perspective. For Ecol Manage. 2003;186:85-97.

Sampson RN. Southern forests: Yesterday, Today, and Tomorrow, In: Michael Rauscher H, Johnsen K, editors. Southern forest science: Past, Present, and Future. Department of Agriculture Forest Service, General Technical Report SRS-75; 2004. p. 408.

Scott DF, Lesch W. Streamflow responses to afforestation with Eucalyptus grandis and pinuspetula and to felling in the Mokobulaan experimental catchments, South African. J Hydrol. 1997;199:360-77.

Scott DF, Bruijnzeel LA, Mackensen J. The hydrologic and soil impacts of reforestation. In: Bonell M, Bruijnzeel LA, editors. Forests, water and people in the humid tropics. Cambridge University Press; 2005. pp. 622-51.

SFA (China State Forest Administration). China's Forest Shelter Project Dubbed "Green Great Wall."' 2006. http://www.chinaview.cn, accessed on July 9, 2006.

Sitch S, Smith B, Prentice IC, Arneth A, Bondeau A, Cramer W, Kaplan JO, Levis S, Lucht W, Sykes MT, Thonicke K, Venevsky S. Evaluation of ecosystem dynamics, plant geography and terrestrial carbon cycling in the LPJ dynamic global vegetation model. Glob Change Biol. 2003;9:161-85.

Shukla J, Mintz Y. Influence of land-surface evapotranspiration on the earth's climate. Science. 1982;215:1498-501.

Shukla J, Nobre CA, Sellers PJ. Amazonia deforestation andclimate change. Science. 1990;247:1322-5.

Sud YC, Shukla J, Mintz Y. Influence of land-surface roughness on atmospheric circulation and precipitation: a sensitivity study with a general circulation model. J Appl Meteor. 1988;27:1036-54.

Sun G, McNulty SG, Shepard JP, Amatya DM, Riekerk H, Comerford NB, Skaggs RW, Swift L Jr. Effects of timber management on wetland hydrology in the southern United States. For Ecol Manage. 2001;143:227-36.

Sun G, Zhou G, Zhang Z, Wei X, McNulty SG, Vose JM. Potential water yield reduction due to reforestation across China. J Hydrol. 2006;328:548-58.

Sun G, Zuo C, Liu S, Liu M, McNulty SG, Vose JM. Watershed evapotranspiration increased due to changes in vegetation composition and structure under a subtropical climate. J Am Water Resour Assoc. 2008;44(5):1164-75.

Sun G, Noormets A, Gavazzi1 MJ, McNulty SG, Chen J, Domec J-C, King JS, Amatya DM, Skaggs RW. Energy and water Balance of two contrasting Loblolly pine plantations on the lower coastal plain of North Carolina, USA. For Ecol Manage. 2010;259:1299-310.

Sun G, Alstad K, Chen J, Chen S, Ford CR, Lin G, Liu C, Lu N, McNulty SG, Miao H, Noormets A, Vose JM, Wilske B, Zeppel M, Zhang Y, Zhang Z. A general predictive model for estimating monthly ecosystem evapotranspiration. Ecohydrology. 2011a;4:245-55. doi:10.1002/eco.194.

Sun G, Caldwell P, Noormets A, Cohen E, McNulty SG, Treasure E, Domec JC, Mu Q, Xiao J, John R, Chen J. Upscaling key ecosystem functions across the conterminous United States by a water-centric ecosystem model. J Geophys Res. 2011b;116:G00J05. doi:10.1029/ 2010JG001573.

Swank WT, Douglass JE. Streamflow greatly reduced by converting hardwoods to pine. Science. 1974;185:857-9. 
Swank WT, Swift LW, Douglass JE. Streamflow changes associated with forest cutting, species conversion, and natural disturbances. In: Swank WT, Crossley DA, editors. Forest hydrology and ecology at Coweeta. Ecological studies, vol. 66. New York: Springer; 1988. p. 297-312.

Swank WT, Vose JM. Long-term hydrologic and stream chemistry responses of southern Appalachian catchments following conversion from mixed hardwoods to white pine. In: Landolt R, editor. HydrologiekleinerEinzugsgebiete: Gedenkschrift Hans M. Keller. BietragezurHydrologie der Schweiz 35. Bern, Schweizerische: SchweizerischeGesellshacft fur Hydrologie und Limnologie; 1994. p. 164-72.

Swank WT, Vose JM, Elliot KJ. Long-term hydrologic and water quality responses following commercial clearcutting of mixed hardwoods on a Southern Appalachian catchment. For Ecol Manage. 2001;143:163-78.

Swift LW. Effect of forest cover and mountain physiography on the radiant energy balance, D.F. Thesis. Durham: Duke University; 1972.

Swift LW Jr, Messer JB. Forest cuttings raise temperatures of small streams in the Southern Appalachians. J Soil Water Conserv. 1971;26(3):111-6.

Swift LW Jr. Lower water temperatures within a streamside buffer strip. Research Note SE-193. Asheville, NC: U.S. Department of Agriculture, Forest Service, Southeastern Forest Experiment Station; 1973. p. 7.

Swift LW Jr. Duration of stream temperature increases following forest cutting in the southern Appalachian mountains. In: International symposium on hydrometeorology. American Water Resources Association; 1982.

Swift LW, Swank WT, Mankin JB, Luxmoore RJ, Goldstein RA. Simulation of evapotranspiration and drainage from mature and clear-cut deciduous forests and young pine plantation. Water Resour Res. 1975;11:667-73.

Swift LW Jr, Swank WT. Long term responses of streamflow following clearcutting and regrowth. Hydrol Sci Bull. 1981;26(3):245-56.

Swank WT, Helvey JD. Reduction of streamflow increases following regrowth of clearcut hardwood forest. In: Proceedings of the symposium on the results of research on representative and experimental basins, December 1970, Wellington, New Zealand. Publication 96. United Nations Educational, Scientific and Cultural Organization-International Association of Scientific Hydrology, Leuven, Belgium; 1970. p. 346-60.

Tian H, Chen G, Liu M, Zhang C, Sun G, Lu C, Xu X, Ren W, Pan S, Chappelka A. Ecosystem net primary productivity, evapotranspiration, and water use efficiency in the southern United States during 1895-2007. For Ecol Manage. 2009;259:1311-27.

United States Department of Agriculture Forest Service (USFS). Watershed management research Coweeta experiment forest, Macro County, North Carolina, Southeastern Forest Experiment Station, Asheville, NC; 1948.

van der Ent RJ, Savenije HHG, Schaefli B, Steele-Dunne SC. Origin and fate of atmospheric moisture over continents. Water Resour Res. 2010;46:1-12.

van der Ent RJ, Coenders-gerrits AMJ, Nikoli R, Savenije HG. The importance of proper hydrology in the forest cover-water yield debate: commentary on Ellison et al. (2012). Glob Change Biol. 2012;18:806-20.

Van Dijk AIJM, Van Noordwijk M, Calder IR, BruijnzeeL SLA, Schellekens J, Chappell NA. Forest-flood relation still tenuous-comment on 'Global evidence that deforestation amplifies flood risk and severity in the developing world' by CBradshaw CJA, Sodi NS, Peh KS-H, Brook BW. Glob Change Biol. 2009;15:110-5. doi:10.1111/j.1365-2486.2008.01708.

Vautard R, Cattiaux J, Yiou P, Thépaut J-N, Ciais P. Northern Hemisphere 1124 atmospheric stilling partly attributed to increased surface roughness. Nat Geosci. 2010;1125(3):756-61.

Vinnikov K, Robock A, Speranskaya NA, Schlosser CA. Scales of temporal and spatial variability of midlatitude soil moisture. J Geophys Res.1996;101(D3):7163-74.

Vose J, Sun G, Ford CR, Bredemeier M, Ostsuki K, Wei X, Zhang Z, Zhang L. Forest ecohydrological research in the 21st century: what are the critical needs? Ecohydrology. 2011;4(2):146-58. 
Vose JM, Ford CR, Laseter S, Dymond S, Sun G, Adams MB, Sebestyen S, Campbell J, Luce C, Amatya D, Elder K, Heartsill-Scalley T. Can forest watershed management mitigate climate change impacts on water resources? Book chapter In: IAHS Revisiting experimental catchment studies in forest hydrology (proceedings of a workshop held during the 25 IUGG general assembly in Melbourne, June-July 2011), IAHS Publ.;2012. p. 353.

Wang JF, Chagnon FJF, Williams ER, Betts AK, Renno NO, Machado LAT, Bisht G, Knox R, Brase RL. Impact of deforestation in the Amazon basin on cloud climatology. Proc Natl Acad Sci USA. 2009;106(10):3670-4.

Wang YP, Kowalczyk E, Leuning R, Abramowitz G, Raupach MR, Pak B, van Gorsel E, Luhar A. Diagnosing errors in a landsurface model (CABLE) in the time and frequency domains. J Geophys Res. 2011;116:G01034. doi:10.1029/2010JG001385.

Waring SW, Waring RH. Forest ecosystems: analysis at multiple scales. 3rd ed. Academic Press; 2007. p. 440.

Watson T. Climate plan calls for forest expansion, USA TODAY. www.usatoday.com/news/ nation/environment/2009-08-19-forest_N.htm (2009).

Wei X, Sun G, Liu S, Hong J, Zhou G, Dai L. The forest-streamflow relationship in China: a 40year retrospect. J Am Water Resour Assoc. 2008;44(5):1076-85.

Wei X, Zhang M. Quantifying+stream flow change caused by forest disturbance at a large spatial scale: a single watershed study. Water Resour Res. 2010;46:W12525. doi:10.1029/ 2010WR009250.

Whitehead PG, Robinson M. Experimental basin studies-an international and historical perspective of forest impacts. J Hydrol. 1993;145:217-30.

Xue Y, Shukla J. The influence of land surface properties on Sahel climate, part I: desertification. J Clim. 1993;6:2232-45.

Yeh TC, Wetherald RT, Manabe S. The effect of soil moisture on the short-term climate and hydrology change—a numerical experiment. Mon Weather Rev. 1984;112:474-90.

Zeng X, Dickinson RE, Walker A, Shaikh M, DeFries RS, Qi J. Derivation and evaluation of global $1 \mathrm{~km}$ fractional vegetation cover data for land modeling. J Appl Meteor. 2000;39:826-39.

Zhang L, Dawes WR, Walker GR. Response of mean annual evapotranspiration to vegetation changes at catchment scale. Water Resour Res. 2001;37:701-8.

Zhang XP, Zhang L, McVicar TR, Van Niel TG, Li LT, Li R, Yang QK, Liang W. Modeling the impact of afforestation on mean annual streamflow in the Loess Plateau, China. Hydrol Process. 2008a;22:1996-2004.

Zhang X. P., L. Zhang, J. Zhao, P. Rustomjiand P. Hairsine. 2008b. Responses of streamflow to changes in climate and land use/cover in the Loess Plateau, China. Water Resour Res. 2008b;44:W00A07. doi:10.1029/2007WR006711.

Zhou, Wei GX, et al. Forest recovery and river discharge at the regional scale of Guangdong province, China. Water Resour Res. 2010;46:w09503. doi:10.1029/2009WR008829.

Zon R. Forests and water in the light of scientific investigation, USDA forest service, Washington, DC. Senate document 469, 62nd congress, 2nd session; 1927. 